\title{
The Impact of Corruption on Economic Development - Kosovo
}

\author{
Rifat Hoxha \\ Kosovo, Prizren; Email: rifati_pz@hotmail.com
}

\section{Doi:10.5901/mjss.2016.v7n3p221}

\begin{abstract}
Many scholars and authors, both national and international, have written about corruption as negative phenomenon in the economic development of the country. A few years ago I also have published a paper on the negative effects that this phenomenon has in foreign direct investment, with the hope that in the future this phenomenon begins to disappear and flourish economic growth and development. The main reason that pushed me to write on this actual subject is the presence and the strengthening of this phenomenon in Kosovo which is somewhat key factor that led to the flight of thousands of citizens from Kosovo. This paper will not appoint persons or institutions who are involved with corruption, but only will attempt to present any damage in economic development of Kosovo as a very small country with great potential and development. In this paper we will try to present some forms of corruption that are emerging in Kosovo, and give some recommendations to overcome or directly combat this phenomenon as harmful to the country's development, for which we debate almost daily, but the concrete results are negative everytime for the country's economy and society.
\end{abstract}

\section{What is Corruption?}

Corruption is an evil which prevents the development of the country's rules of law, strengthening of democracy, fairness, social justice, and economic growth. It is impossible for a country with a high degree of corruption to have perspective and normal development.

Corruption does not affect only the economic damage but damages the overall welfare of a nation. Corruption occurs mostly in developing countries and in their transition phase, but is very common in developed countries. By (UNODC 2011), corruption also affects the development and growth of private businesses. According to their research the private businesses use their connections with various government officials who for personal interests help them be more favored towards competition. So from this we can see that corruption is affecting the trade of a country and legal business that fills states kitty is directly damaged.

These businesses have nearly impossible to compete with businesses that are favored by corrupt officials and often these businesses are forced to close. In our country this negative phenomenon is widespread and often the succes of favored businesses compared to other businesses can be seen clearly. It has been and it is very disturbing that it CONTINUES the massive flight of people of Kosovo almost in an organized way to western countries.

Among the refugees there were also businessmen, engineers, managers, doctors, economists, lawyers of different artisans for whom our country will always be in need. Frightening fact is when a large part of people without any hesitation and at the first opportunity turned away from theirselfs and fled the country for their contribution in a foreign country where they will be offered better conditions for work and life. And in the case of Kosovo is frightening that even domestic institutions and international ones claimed that Kosovars are fleeing illegally without proper documentation or as people say "in the black".

I do not understand how a citizen can travel organized and monitored by local and international media, pass some state borders, depending on where they intended to achieve, and to say that these people are illegally crossing the state border. Where are the local and international institutions in this case? However, as economist I worry more about the willingnes of my people to leave the country, than the way that they choose to do it.

\section{Consequences of Corruption in Economic Development of the Country}

According to many economists in our country corruption is a direct impact on development and economic growth in Kosovo. Authors (Javed Mahmood Jasra, Hunjra Imran Ahmed, Aziz Ur Rehman II, Rauf I. Azam, Muhammad Asif Khan 2011), point out that small businesses are considered as the engine of economic growth in the world and have developed a healthy competition. By (Mustafa 2008), corruption has negative effects on distortion of competition, the deregulation of the business environment and investment climate and unfortunately there is a perception of businesses, but also of the 
opinion that corruption has been growing recently.

Of course it affects the growth of transactions, ie. business expenses; It undermines public budget and sends serious investors away. In a written document (Konushevci 2008), President of the Economic Chamber of Kosovo Mr. Gwrxhaliu says the source of corruption and what really hinders economic development process in Kosovo is at the governmental institutions, the very places where falling decisions take various activities. And, ultimately, corruption is protected by certain interest groups, political parties, and individuals who use or collect the fruits of the current revolution. The dire economic situation for most people, and high unemployment rate are concerns which must be taken more seriously by our leaders.

As a result of the corruption of our people it has been the rejecton of visa liberalization, remaining as the only country in the Balkans without the right of free movement.

By (Zeka 2015), the presence of corruption is sufficating and is hindering the development of businesses that promotes business values. According to him the presence of corruption prevents the involvement of the public procurement activities of businesses which compete with more economically advantageous bid and higher quality products.

\section{The Types of Corruption that are Emerging in Kosovo}

As in many other places in Kosovo are shown different forms of corruption. By (Krasniqi 2013), types of corruption shown in Kosovo are: political corruption, financial corruption, crime, moral and material corruption. Forms through which the activity is performed corruption are as diverse as bribery, accepting gifts, extortion, nepotism, preferential treatment, abuse of funds, misappropriation of confidential information and forms discussed in our country share.

These forms of corruption can be found in almost all institutions of our country, from the judiciary, government, healthcare to education and low overhead. By (Krasniqi 2013), the most severe form of corruption is political corruption. Forms of political corruption are important because they directly affect the future of the state and society. It is precisely officials who are elected by the people those who have responsibility for the success or failure of a country to its growth and development. By (KDI 2015), nepotism, employment of family members, the exercise of two or more jobs of employees in the public sector and private-conflicts of interest, the bureaucracy or the division of tenders party affiliation, judging by economic liberalism, all these necessarily lead to possible economic crisis with recessive consequences. In our country is a widespread belief that a private businessmen has no opportunity to get a job from institutions in the country if there is no access or knowledge with institutional officials. It also negatively affects the development of legal businesses that feeling between unequal competition are automatically promoted to pass or to violate the laws for their benefit and to the detriment of economic development. It is very disturbing statement of some businesses that were visited to complete this research that "it is impossible to continue their activity if applied to all fiscal rules", they raise concerns are precisely the institutions that should be interested on installing a fair competition within the Kosovo market. It is to be noted the concern of some manufacturing businesses stipulating that until we, as serious companies, are not protected from competition from the informal to the local market, what will happen to us in the future when we integrate in EU and start to implement the agreement on the trade free between international countries. Kosovo businesses need more for a regular market where the law is applied strictly ,as not to waste energy being protected from competition from informal or get really deep into it, but to work and research regularly for products and practice changes in business which would lead to the growth of their performance.

\section{Who Should Fight Corruption?}

By (Levan 2012), no one is fighting corruption because those who should be fighting corruption are convenient for this situation and are benefiting from it. But I personally can not agree with this idea because, in our institutions there are very clean officials who for no price given would do harm or would work in the country's development of personal interests. I think to answer the question of who should fight corruption, the answer would be all of us. People are the ones who appoints their leaders and if they are not satisfied with their results can collect and dismiss them. The easiest way to fight corruption is the awareness of every citizen to report such negative phenomenon whoever the face is. Even internationals think that will have to do more about fighting corruption, because of the experience 16 years after the war did not have satisfactory results from their concrete to combat this negative phenomenon.

Without attempting to blame international delegate for the above rate of corruption in Kosovo, we think the international community are aware of the full details of the situation in Kosovo and have the option but not sufficient will to fight this negative phenomenon. We as a people need to become aware and to not expect others to do all the work, but 
work hard and together with international support to help in the fight against corruption in our country by influencing the growth and economic development. Everytime government efforts to improve the state of Kosovo's economy is welcomed, but now is the time to have something more concrete.

We can even boast state laws and regulations that meet international standards, however, can not boast of their implementation. It is time that all together to fight this negative phenomenon, working and training to an international market and to show that we are ready with the help of international friends to provide foreign investors but also locals to invest their savings in Kosovo as a country with a future perspective.

\section{Conclusions and Recommendations}

We can not say that in this paper we managed to draw a new conclusion regarding the effect of corruption on economic development. However, what we found and that is very worrying in our country that as a result of corruption and poor economic situation the citizens of Kosovo are able to leave the country at the first opportunity given. I think that it is therefore very hard to put our institutions to work more seriously and more specifically in the social welfare and development of the Kosovo market. Informal competition which turned out to be more pronounced in Kosovo and implemented in various forms was the main concern of many legal businesses and negatively affected their strategic plans. To pass this thing the Kosovo government should be more closely involved in supporting businesses in various forms and by providing a secure market.

The greatest help that can be given to citizens and legal businesses is ongoing quality control of goods, especially food. Another conclusion that was drawn from this research is not the willingness of individuals to present cases of corruption that although there is a very easy form of anonymity they can be identified and are being blackmailed. We hope that in the future those who report corruption will be supported because they are heroes just because they contribute to the development of the country. I think that the institutions of Kosovo together with the international community should develop a strategic plan on fighting corruption and economic development. This negative phenomenon is kept so isolated that we as peoples in the Balkans are not only not enjoying the freedom of movement but it is also affecting the increase of the living cost and slowing down the economic growth. We hope that institutions and our people will be aware and will work together for a strong state law and a developed economy where people are not going to have no need to migrate to a better life.

\section{References}

Javed Mahmood Jasra, Ahmed Imran Hunjra ,Aziz Ur Rehman II, Rauf I. Azam, Muhammad Asif Khan . "Determinants of business of small and medium enterprises." Internacional Journal of Buzsiness and Social Science, 2011: Vol 2 Nr 20.

KDI. "Korrupsioni." Prishtine, 2015.

Konushevci, Arton. evropaelire.org. 12 2, 2008. http://www.evropaelire.org/a/1355436.html (accessed 04 02, 2016).

Krasniqi, Jakup. zeri.info. 04 18, 2013. http://old.zeri.info/artikulli/4108/format-e-korrupsionit (accessed 04 02, 2016).

Levani, Darien. Kush e lufton korrupsionin? Tirane: Quotidiano albanese online, 2012.

Mustafa, Muhamet. Sa ndikon korrupsioni ne zhvillimin ekonomik. Prishtine: Instituti Riinvest, 2008.

UNODC. " Korrupsioni ne Shqipwri: ryshfeti sipas pwrvojws sw popullsisw." Tirane, 2011.

Zeka, Arian. zeri.info. 04 10, 2015. http://zeri.info/ekonomia/27755/s-ka-vullnet-per-luftim-te-korrupsionit/ (accessed 04 02, 2016). 